\title{
A mobil Internet jövője a mezőgazdaságban
}

\author{
Róbert Szilágyi ${ }^{1}$
}

\section{N F O}

Received 12 April 2010

Accepted 19 May 2010

Available on-line 31 May 2010

Responsible Editor: K. Rajkai

\section{Keywords:}

mobile devices, mobile Internet, mobile application, agriculture

\section{N F O}

Beérkezés 2010 Április 12.

Elfogadás 2010 Május 19.

On-line elérés 2010 Május 31.

Felelős szerkesztő: Rajkai K

\section{Kulcsszavak:}

mobil eszközök, mobil Internet, mobil alkalmazások, mezőgazdaság

\section{$\underline{\text { A B S TRACT }}$}

While studying the use of mobile communication devices it can be concluded that different types of wireless communications networks offer different services. The interpretation of the mobile Internet in the technical literature is fully unambiguous and may give rise to misunderstandings although it can be regarded to be a well defined area. Mobile systems develop very dynamically both as regards the speed of data transmission and services. The third generation technology (3G) and the wireless network (Wi-Fi) are similar and different in various respects. The wireless access to the Internet can be realised with several different technical solutions. However, the business assessment of the mobile technology must not be done only on the basis of the technology and taken out of its environment randomly since the whole area is very complex. The Internet technology and the Internet network have become essential communication tools in business processes recently. Using the Internet by means of mobile appliances increases the possibilities. If we study the business process the expenses, advantages, disadvantages can be seen well. Nowadays these applications are more and more successful in the following areas such as in agriculture, in different parts of food industry, in extension services, precision agriculture and logistics.

\section{ÖS S Z E F O G L A L Ó}

A mobilkommunikációs eszközök vizsgálata során megállapítható, hogy a számos vezeték nélküli hálózati lehetőség a szolgáltatások végtelen tárházát nyújtja. Bár a mobil Internet teljes definíciója technikai értelemben még nem teljesen kiforrott, ugyanakkor egyes részterületei nagyon pontosan meghatározottak. A mobil eszközök mind az adatátvitel sebességében, mind a szolgáltatások minőségében dinamikusan fejlődnek. A harmadik generációs hálózatok (3G) és a vezeték nélküli hálózat (Wi-Fi) esetében sok a hasonlóság, de számos különbség is megfigyelhető. A vezeték nélküli Internet elérése számos technikai megoldással lehetséges. A mobil technológia üzleti kontextusa nagyon összetett és komplex terület. Az Internet technológia napjainkra az üzleti folyamatokban meghatározó kommunikációs eszközzé vált. Az Internet mobil eszközökkel történő elérése növeli a lehetőségeket. Ha az üzleti folyamatokat tanulmányozzuk az Internet előnyei, hátrányai, költségei jól meghatározhatók. Napjainkban ezek az alkalmazások egyre hatékonyabbak a mezőgazdaságban, az élelmiszeripar egyes területein, a vidékfejlesztésben, a precíziós gazdálkodásban és a logisztikában.

\section{Bevezetés}

A mobil kommunikációs eszközökkel való Internet elérést és szolgáltatások használatát a nemzetközi irodalomban széles körben a „mobil Internet” kifejezéssel jelölik, melynek használata a magyar szakirodalomban is elterjedt.

A vezeték nélküli hálózat lehetővé teszi az emberek számára, hogy vezeték nélkül kommunikálhassanak, és különböző alkalmazásokhoz és információkhoz férhessenek hozzá helytől és időtől függetlenül, ami mozgási szabadságot biztosít.

A vezeték nélküli kommunikációs rendszereknek számos típusa létezik, de ezen hálózat egyik megkülönböztető jellemzője az, hogy itt a kommunikáció számítástechnikai eszközök között zajlik. Ilyen eszköz többek között a kéziszámítógép vagy a digitális személyi titkár (PDA - Portable Digital

\footnotetext{
${ }^{1}$ Róbert Szilágyi

University of Debrecen, 4032 Debrecen, Böszörményi út. 138, Hungary

szilagyir@agr.unideb.hu
} 
Assitant), a hordozható számítógép (laptop), az asztali személyi számítógép, a szerver és a nyomtató. Ezek a számítástechnikai eszközök processzorral, memóriával és meghatározott típusú hálózathoz való csatlakozásra alkalmas egységgel rendelkeznek. A hagyományos mobiltelefon nem tekinthető számítástechnikai eszköznek, ugyanakkor az újabb telefonkészülékek egyre gyakrabban tartalmaznak számítógépes funkciókat és a számítógép-hálózati csatlakozást biztosító hálózati adaptereket. A jövőben a legtöbb elektronikai eszköz lehetőséget teremt majd vezeték nélküli hálózati összeköttetés létesítésére (Geier, 2005 nyomán).

A mobil Internet definíciója Dárdai szerint (Dárdai, 2002) a következő: a mobil Internet „a mobil távközlés és a mobil hálózat legfontosabb szolgáltatása, előnye és lényegi tulajdonsága az, hogy az előfizető az ellátottsági területen belül tetszőleges helyen, mozgás közben is, összeköttetést létesíthet a hálózattal, a hívott féllel. A létrejött összeköttetés fennmarad akár mozgás közben, miközben a mobil állomás jogosultsága szerint a felhasználó a hálózat szolgáltatásaihoz folyamatosan hozzáférhet.”

A mobil Internet hozzáférésnek jelenleg két fó irányvonala van. A 3G (harmadik generációs mobiltelefon hálózat) és a Wi-Fi (WLAN- Wireless Local Area Network - vezeték nélküli helyi hálózat) szabvány lehetővé teszi a nagy sávszélességü hozzáférést. Érdemes ezért a hasonlóságokat és különbségeket röviden áttekinteni (Korhonen, 2003):

Hasonlóságok:

- mindkettő vezeték nélküli (számottevő előny a kábelek mellőzése, a nagyobb mobilitás),

- mindkettő hozzáférési technológia (tulajdonképpen a vezetékes hálózat utolsó szegmensébe beépülve lehetővé teszi a hálózat olyan helyekre való kiterjesztését, ahová a kábeleket nehezen, vagy túl költségesen tudnánk kiépíteni),

- mindkettő nagy sávszélességet kínál (a jelenlegi ISDN és analóg telefonos kapcsolatokhoz képest nagyságrendekkel nagyobb sávszélességet biztosítanak),

- mindkettő lehetővé teszi a folyamatos hozzáférést (a „mindig, mindenhol hozzáférhető” hálózat használatából fakadó előny talán a legnagyobb a felsoroltak közül).

Különbségek:

- eltérö üzleti modellek, telepítési környezet (a $3 \mathrm{G}$ alapvetően a mobiltelefon szolgáltatásait bővíti ki, míg a Wi-Fi a számítógépes hálózati kapcsolatokra van specializálva, de ugyanakkor egyéb alkalmazási alternatívákat is magukban hordoznak),

- frekvencia használat jogi és menedzselési kérdései (a 3G frekvenciája engedélyköteles tenderezéssel döntenek az engedélyekről -, míg a Wi-Fi jelenleg nem engedélyköteles),

- a technológiai fejlettségi szintjük különböző. (Lehr és McKnight, 2003)

\section{A mobil szolgáltatások várható fejlődése}

Az elkövetkezendő 3-5 évben a vezeték nélküli hálózat számos új technológiával fog bővülni: WiMax (Worldwide Interoperability for Microwave Access - mikrohullámú hozzáférések világméretü kompatibilitása), UWB (Ultra WideBand Radio - ultra szélessáv) és az úgynevezett csomós hálózatok (Mesh Networks). A WiMax nagy sávszélességet biztosít a fix, mozgékony és vándorló felhasználóknak egyaránt. Nagy elönye, hogy 50 km feletti hatótávolsággal rendelkezik.

Az OECD 2006-ban kiadott WiMax szabvánnyal foglalkozó tanulmánya szerint (OECD, 2006) a WiMax jól illeszkedik a jelenlegi Internet-hozzáférési struktúrához. A jelentés ugyan nem közöl konkrét adatokat, de érzékelteti az egyes technológiák egymáshoz viszonyított jellemzőit. Mobilitás szempontjából a 3G jobbnak minősül a WiMaxnál, de sebességben a WiMax nagyobb (megközelíti a DSL kapcsolatét). Az adatátvitel költségeit vizsgálva egyértelmüen kedvezőbb a WiMax helyzete, a vezeték nélküli kapcsolatok közül a Wi-Fi előzi meg. A biztonsági tényezőket tekintve a WiMax fejlesztése során igyekeztek kiküszöbölni a Wi-Fi problémáit. 
Az UWB nagyon alacsony feszültséggel adatokat továbbít széles frekvenciasávon. Jelenleg még a szabványok kialakítása van folyamatban, de a Wi-Fi-hez képest négyszeres sebességet fele akkora áramfogyasztással éri el.

A Mesh networks egy új “ad hoc” hálózati technológia, amely Wi-Fi kapcsolaton keresztül osztja meg a felhasználók között az Internetet. Az eszközök nem csak végpontok, hanem ugyanakkor routerként is viselkednek. Ezen hálózatok nagyon megbízhatóak. Egy adott régió (térség, falu) számára ingyenes, vagy nagyon olcsó Internet hozzáférést biztosíthat (Hebel, 2006).

Telekommunikációs szolgáltatásoknál a megfelelő szolgáltatásnak a következő feltételeket kell teljesítenie:

- egyszerủ és felhasználóbarát számlázási módszer,

- alacsony Internet szolgáltatási költség (hozzáférés, navigáció, letöltés, stb.) és alacsony vagy ingyenes nemzetközi IP alapú telekommunikáció,

- egyszerü hozzáférés és bejelentkezés,

- kibővített és biztonságos hozzáférés (titkos adatok elérése bármilyen hálózatból), kellően rugalmas vezeték nélküli szolgáltatás (várakozási idő csökkentése).

\subsection{Az alkalmazható mobil eszközök legújabb típusai}

\section{Felsőkategóriás „okostelefon”}

Ezeket az eszközöket elsődlegesen a nagyobb erőforrásigénnyel bíró üzleti, vállalati alkalmazásokra fejlesztették ki. Kinézetüket tekintve a mobiltelefon és a PDA készülékek között helyezkednek el, bár inkább tekinthetők PDA-nak mint telefonnak. Egyes készülékek teljes billentyüzetet tartalmaznak. A legújabb készülékekre egyszerüen lehet alkalmazásokat telepíteni. A J2ME (Java 2 Micro Edition - mobil készüléken futó Java) alkalmazások támogatása egyértelmű. Az Apple által piacra dobott iPhone és azok klónjai úgy tünik követendö irányt adnak a mobiltelefon fejlesztőknek.

\section{Handheld PC}

A készülékek kinézetüket tekintve a laptopokra hasonlítanak, azzal a fontos különbséggel, hogy lényegesen kisebb kijelzővel és fizikai mérettel rendelkeznek. A kisebb méret miatt könnyebben mobilizálhatók, olyan helyeken is alkalmazhatók, ahova nem célszerü laptopot vinni. Gyengébb számítási teljesítményüket kisebb energiafogyasztásuk kompenzálja.

\section{NetBook}

Az utóbbi pár évben megjelent újabb kategória töretlen népszerüségnek örvend, egyre többet adnak el belőlük. A készülékek méretüket tekintve a laptopok és a PDA-k között helyezkednek el. Általában majdnem teljes billentyüzettel és viszonylag kicsi kijelzővel rendelkeznek. A laptopnál kisebb méret miatt könnyebben mobilizálhatók, olyan helyeken is lehet velük elsődlegesen böngészni ahol az eddig körülményes volt. A számítógépgyártók igazi sikerterméke, az ágazat ennek a típusnak köszönhetően a prognosztizált csökkenés ellenére mérsékelt növekedést érhetett el. Manapság nincs olyan gyártó aki ezen sajátos hordozható eszköz kategóriájában nem rendelkezne önálló típussal.

\section{Tablet PC, teljesen érintőképernyős PC}

A Microsoft vezetésével kifejlesztett Tablet PC kialakítását tekintve nagyon hasonlít egy laptophoz. Fő előnye abban rejlik, hogy a teljes készülék intelligens jegyzetfüzetként használható a teljes számítógép-funkció megtartása mellett. A nyomás-érzékeny képernyő segítségével hatékonyabb az adatbevitel, kisebb energiafogyasztása pedig hosszabb használatot eredményez. A néhány éve, relatíve korán megjelent eszközök mérsékelt sikerének köszönhetően egészen mostanáig nem jelentek meg klónjaik. A 2010 tavaszán az Apple által kiadott iPad megváltoztathatja ezen kategória népszerüségét, egyes elemzők szerint a jövő sikertörténete lehet. 
A jövő eszközeinél a fontos hardver elemek a következők lesznek: erősebb processzor, nagyobb felbontású kijelző, több memória, integrált vezeték nélküli kapcsolat, bővítőkártyák.

A mobil eszközök számos szolgáltatást nyújtanak. A megfelelő szolgáltatáshoz szükséges eszköz kiválasztása a költségek mellett számos kritérium alapján történhet. Az eszközök kiválasztása során a következőket vehetjük figyelembe:

- eszköz mérete és tömege,

- rendelkezésre álló memória mérete,

- processzor típusa, sebessége, energiafogyasztása,

- képernyő mérete, színmélysége, láthatósága,

- operációs rendszer, frissítési lehetőség,

- bővítő-csatlakozók, bővíthetőség,

- akkumulátor kapacitása, használati idő,

- integrált lehetöségek (Bluetooth, Wi-Fi, infravörös átvitel, billentyüzet, kamera),

- $\quad$ szoftvertámogatás, fejlesztések, alkalmazások.

\section{Tipikus mezőgazdasági alkalmazási lehetőségek}

A mezőgazdasági alkalmazásokat vizsgálva megállapítható, hogy a mobil technológiák és a mobil Internet technológiák fejlödésével, a mobil kommunikációs szolgáltatások árainak csökkenésével a mezőgazdasági alkalmazások száma is folyamatosan növekszik (Herdon, 2006). Az általános célú használat (elektronikus levelezés, a WWW szolgáltatásokon keresztül történő információ elérés) mellett a hely- és idö-független specifikus alkalmazások iránti igényeket és lehetőségeket a vizsgált alkalmazások igazolták.

\section{Mobil eszközök a precíziós termelésben és gazdálkodásban}

A precíziós gazdálkodási technológia egyre népszerübbé válik a gazdálkodók körében, hiszen ezzel a technológiai módszerrel lehetőség van a helyi igényekhez igazodó vetőmag, mütrágya, növényvédő szer differenciált kijuttatására, a müveletek módjának táblán belüli változtatására.

A precíziós gazdálkodás feltételrendszerét a GPS (Global Positioning System - müholdas helymeghatározó rendszer), megfelelő regisztrálási technika, informatikai, térinformatikai háttér, megbízható adatbázis és szaktanácsadó rendszer valamint a változtatható adagolásra képes vetö-, permetező- és mütrágyaszóró gépek jelentik. A globális helymeghatározás korábban csak katonai célokat szolgált, de mára fokozatosan teret nyert a polgári életben, így a mezőgazdaságban is. A pontos helymeghatározás elengedhetetlen a hozamtérképek készítéséhez és a terület-specifikus agrotechnikai beavatkozások megvalósításához.

A térinformatikai szoftverek megjelenése az adatok térképszerü ábrázolását, tetszés szerinti manipulálását és a precíziós gazdálkodáshoz nélkülözhetetlen, úgynevezett digitális adatbázisok felépítését tette lehetővé. Az automatizált mezőgazdasági gépek segítségével elvégezhető többek között a hozammérés, a terület adottságai szerint változó mütrágyaszórás, a táblán belüli gyomviszonyokhoz igazodó gyomirtás. Tulajdonképpen minden olyan agrotechnikai beavatkozás terület-specifikusan elvégezhetö, ahol figyelembe kell, vagy lehet venni a talajok tér- és időbeli változatosságából adódó eltérő igényeket (Busznyák, 2004).

A precíziós gazdálkodás által igényelt térképi adatok kezelését nagy sávszélesség nélkül nem lehet megoldani. A vezeték nélküli technológiák közül a müholdas átvitel és a WLAN kínálkozik jó alternatívának. A müholdas adatátvitel előnye a nagy területi lefedettség, hátránya a még mindig magas ár. A nehezen megközelíthető farmokon Internet kapcsolatot müholdon keresztül lehet kialakítani, majd a farmon belül WLAN elérési pontok segítségével lehet az eszközöknek 
kommunikálni. Az elérési pontokat úgy kell elhelyezni, hogy a farm teljes lefedettsége biztosítva legyen.

Az egyre több szenzorral ellátott mobil laborok teljes képet nyújthatnak akár a precíziós szőlészetben is (Mazetto et al., 2009 a). Az optikai és ultrahangos szenzorok eredményei alapján sokkal pontosabb képet kaphatunk a tényleges érettségi állapotról.

A precíziós gazdálkodás egyik nagy problémája a rendszerek használhatóságának kérdése. A szakértők szerint ez az oka annak, hogy nem terjednek el ezek az eszközök olyan ütemben, ahogy azt előzetesen gondolták. A gazdálkodók feladataik végzése során nem tudják teljes mértékben kihasználni a rendelkezésre álló technológiát. Az elektronikus eszközöknek meg kellene könnyíteniük a munkát, ezzel szemben a túl sok információ és a túl bonyolult kezelőfelületek inkább rontanak a helyzeten. Ezen kívül munka közben a körülmények közel sem mindig ideálisak, input-output lehetőségek szintén végesek (billentyüzet hiánya illetve limitáltsága, mutatópálca, kisméretủ képernyő, stb.).

\section{Vezeték nélküli adatbevitel, adat-felvételezés}

Az adat-felvételező eszközöket nagy távolságon is alkalmazható Wi-Fi technológiával érik el. A nagyobb távolságot az irányított antennák biztosítják. Egy mozgatható antennát a farm épületére helyeznek el, amely folyamatosan követi a traktor mozgását. A másik antennát pedig magára a traktorra úgy kell elhelyezni, hogy mindig egy adott tartomány irányába nézzen. A nagyobb távolságok áthidalása érdekében a távlati jövőben meg kell oldani az adatok továbbítását, amire vezeték nélküli adatátjátszók és akár müholdas átvitel jöhet szóba.

A kliens szerver kapcsolaton alapuló, vezeték nélküli technológiával müködő farm monitoring rendszereknek a mobil Internet nagy lehetőségeket nyújt. Az adatgyüjtésre használható céleszközök segítségével lehetővé válik az, hogy a teljes farmról annak minden változóját az alapanyagoktól a termékekig valósidőben érhető el információ (Mazetto et al., 2009 b). Az egyre gyorsuló 3G-s szolgáltatásoknak van egy sajátos mellékterméke, a „régi” GPRS (General Packet Radio Service általános csomagkapcsolt rádiószolgáltatás) kapcsolat adatgyüjtésre megfelelő sávszélességre egyre olcsóbban és egyre szélesebb körben érhetö el. Jellemzően a gépekre elhelyezett adatgyüjtő készülékek integráltan tartalmazzák a GPS és GPRS modulokat.

\section{Zöldség-gyümölcs menedzsment}

A dán fejlesztésű (Jensen és Thysen, 2005) mobil Internet alapú zöldség-gyümölcs termelés menedzselő rendszer jól szemlélteti a lehetőségeket. A rendszer lehetővé teszi a termelö, a mezei munkát végző, a szakértő és a kereskedő információ igényének kielégítését. A termelőnek és a munkásnak elsődlegesen a termeléshez és mindennapi munkavégzéshez szükséges információkat kell elérni. A szakértő számára a termelési adatok a legfontosabbak. A kereskedő az ár, mennyiség és a termék származási helyére és a nyomon követési információkra kíváncsi. A fejlesztés során figyelembe vették a készülékek limitált kijelzőit és böngészés kötöttségét. A fejlesztési platform XHTML volt, így lehetővé vált, hogy PC-n és mobil eszközön is használható legyen az alkalmazás. A fejlesztők a későbbiekben termésbecslés funkcióval, valamint a termék nyomon követés szélesítésével tervezik bővíteni a rendszert.

\section{Állattenyésztés}

Az állatok különböző intelligens azonosítókkal való ellátása megteremti a lehetőséget arra, hogy azok pontos térbeni pozícióját és akár élettani adatait valósidőben el lehessen érni. Érdekes felvetést fogalmaznak meg az állatjólléti elveknek megfelelő élőállat nyomon követő GPS alapú készülékek. Az állatokat a korábban elterjedt elektromos sokkolás (villanypásztor) helyett hangjelzéssel tartanák a birtokhatáron belül (Umstatter et al., 2009).

\section{Összegzés}

A mobilkommunikációs eszközök vizsgálata során megállapítható, hogy a számos vezeték nélküli hálózati lehetőség szolgáltatások végtelen tárházát nyújtja. A mobil eszközök mind az adatátvitel sebességében, mind a szolgáltatások minőségében dinamikusan fejlődnek. A vezeték nélküli Internet 
elérése számos technikai megoldással lehetséges. Napjainkban, mint az élet sok más területén a mezőgazdaságban is egyre jobban elterjednek a mobil alkalmazások. A döntéshozók egyre növekvő és azonnali információigényét jól szolgálhatják ezen szolgáltatások. A szükséges infrastruktúra kiépülésével számos olyan terület körvonalazódhat, melyre a jövőben jól lehet támaszkodni.

\section{Hivatkozások}

Busznyák J. (2004): Mobil eszközzel is elérhető térinformatikai és egyéb adatbázisok fejlesztése, Acta Agraria Kaposváriensis Vol 8 No 3, ISSN 1418-1789, 61-75 p.

Dárdai Á. (2002): Mobil távközlés, mobil Internet, (Mobil ismeret) ISBN 963440996 2, 252-253 p.

Hebel M. A. (2006): Meeting Wide-Area Agricultural Data Acquisition And Control Challenges Through Zigbee Wireless Network Technology, ASABE 234-239 p.

Herdon M., Zimányi K., Péntek Á. (2006): e-Factors in e-Agribusiness, XII. European Conference Information Systems in Agriculture and Forestry on Through scientific development to prosperity 2006 16-17 May, Prague, ISBN 80-213-1494-X

Jensen A. L., Thysen, I. M.B. (2005): Management in Fruit and Vegetable Production with Mobile Internet, EFITA/WCCA 2005, ISBN 972-669-646-1, 484-489 p.

Korhonen J. (2003): Introduction to 3G Mobile Communications Second Edition, Artech House, ISBN 1580535070

Lehr W., McKnight L.W. (2003): Wireless Internet access: 3G vs. WiFi?, Telecommunications Policy No.27, 351-370p.

Mazzetto F., Calcante A., Mena A., Vercesi A. (2009): Development and first tests of a mobile lab combining optical and analogical sensors for crop monitoring in precision viticulture, Precision agriculture '09, Wageningen, ISBN 978-90-8686-113-2, 31-38 p.

Mazzetto F., Calcante A., Salomoni F.(2009): Development and first tests of a farm monitoring system based on a client-server technology, Precision agriculture '09, Wageningen, ISBN 978-90-8686-113-2, 389-396 p.

OECD (2006): The Implications of WiMax for Competition and Regulation, Azonosító:

DSTI/ICCP/TISP(2005)4/FINAL, 02-Mar-2006

Preez G. T., Pistorius C.W.I. (2002): Analyzing technological threats and opportunities in wireless data services, Technological Forecasting \& Social Change 70, 1-20 p

Umstatter C., Tailleur C., Ross D., Haskell M.J. (2009): Could virtual fences work without giving cows electris shocks?, Precision livestock farming ’09, Wageningen, ISBN 978-90-8686-112-5, 161-168 p. 